\title{
Inequities as a social determinant of health: Responsibility in paying attention to the poor and vulnerable at risk of COVID-19
}

\author{
Salah Eddin Karimi, ${ }^{1}$ Sina Ahmadi, ${ }^{2}$ Neda SoleimanvandiAzar ${ }^{3}$ \\ ${ }^{1}$ Social Determinants of Health Research Center, Health Management and Safety Promotion Research Institute, \\ Tabriz University of Medical Sciences, Tabriz; ${ }^{2}$ Department of Social Welfare Management, Social Welfare \\ Management Research Center, University of Social Welfare and Rehabilitation Sciences, Tehran; ${ }^{3}$ Preventive \\ Medicine and Public Health Research Center, Psychosocial Health Research Institute, Iran University of Medical \\ Sciences, Tehran, Iran
}

\section{Dear Editor,}

In December 2019, in Wuhan, Hubei province, China, a disease of viral origin was identified among people working in or around the seafood and animal market. ${ }^{1}$ COVID-19 is a causative agent of acute respiratory syndrome. Almost $26-36 \%$ of patients need special care and about $4-15 \%$ of them die. Due to the lack of vaccines and effective treatment, the best way to prevent its spread is to quarantine patients and track their contact with other people in the community, trying to reduce mortality and protect the elderly, the vulnerable and special patients. , $^{2,3}$

It is not the first epidemic causing deaths and social-economic effects, and it is not the last one. Although, the burden of this disease affects all communities and individuals in every class, it seems to have a greater negative impact on poor and vulnerable people. As it is notable, poverty is itself a risk factor for underlying diseases such as asthma, hypertension and diabetes, and as studies have shown, these conditions are risk factors for death from COVID-19. ${ }^{4}$ Furthermore, studies have illustrated that health inequality is in favor of the rich, and that the incidence of disease is higher among the poor and other vulnerable groups. ${ }^{5}$ Social vulnerability highlights social, economic, demographic, and geographic characteristics that determine not only risk exposure but also community capacity to deal with, respond to, and recover from natural disasters and hazards. ${ }^{6}$

The lives of vulnerable people are at risk for several reasons; including job loss, lack of income and being forced to leave home quarantine to go to work especially by public transport, which can increase the risk of infection and virus transmission to other family members and the community, this could ultimately lead to morbidity and mortality. ${ }^{7,8}$ Previous studies have also shown that people with lower socioeconomic status tend to live in a crowded places, therefore, these people are more exposed to the virus due to their neighborhood conditions, and it seems that because of living conditions, unemployment, low income, lower level of awareness, and cultural habits, ${ }^{9-12}$ this group is less likely to seek treatment and therefore they utilize less health services. ${ }^{13}$
In COVID-19 disease, this vulnerable population is more unequally affected and as mentioned above, they are more exposed to the virus and loss of their health, jobs and insurance, so they deserve more care. This is while, currently $55 \%$ of the world's population do not have any social protection, $40 \%$ do not have any health insurance and only $20 \%$ use unemployment insurance benefits. ${ }^{14,15}$

Although, COVID-19 has a biological origin, it could be considered as a social problem because it has both social causes and social consequences. ${ }^{16}$ COVID-19 disease is associated with socio-economic context, lifestyle and the extent of social communication, which causes its transmission and prevalence, and as a social problem, it has disrupted the quality of life of most societies by creating stress and disrupting social and economic activities. Therefore, as an innovation and warning referred to in this letter, the world's health systems and governments must take steps to combat this disease in vulnerable groups specifically. In order to reduce the social consequences of emerging diseases, such as SARS, MERS, Ebola arrangements and policies of successful countries should be considered, and documented in the form of protocols and protective laws need to be enacted regarding vulnerable groups.

\section{What should be done?}

- Supporting vulnerable groups by governments, policymakers and non-governmental organizations;

- Providing essential health services to high-risk and vulnerable people;

- Legislating and implementing social policies to reduce the economic burden of COVID-19 disease and allocating support packages to the poor and vulnerable;

- Raising cultural sensitivity, informing through cyberspace media;

- $\quad$ Providing free access to diagnostic tests of COVID-19.

Significance for public health

The social nature of COVID-19 disease requires that all social capacities, including prevention and socio-economic policies, be used to prevent and control it as much as possible in order to reimburse and compensate the lost income of the affected strata in the form of financial and livelihood assistance. 


\section{Conclusion}

The social effects of coronavirus will continue in the post-corona period, and poverty seems to be one of its most important enduring sustainable effects.

Therefore, the social nature of COVID-19 disease requires that all social capacities, including prevention and socio-economic policies, be used to prevent and control it as much as possible in order to reimburse and compensate for the lost income of the affected strata in the form of financial and livelihood assistance.

Accordingly, it seems that countries and policymakers must legislate long-term laws to improve social welfare and pay attention to insurance along with livelihood assistance and income compensation. Allocating a supportive insurance fund for this type of pandemic with the participation of members of the society can be a fundamental step, in order to deal with some of the negative consequences of these diseases in times of crisis.

Finally, it should be noted that it is necessary to stop drug sanctions in all countries, and international organizations should take steps in the direction of humanitarian services to provide pharmaceutical and health assistance to countries, such as Iran, without any restrictions.

Correspondence: Neda SoleimanvandiAzar, Preventive Medicine and Public Health Research Center, Psychosocial Health Research Institute, Iran University of Medical Sciences, Tehran, Iran.

E-mail: soleimanvandi.n@iums.ac.ir

nedasoleiman@yahoo.com

Key words: Social determinant of health; COVID-19.

Conflict of interest: The authors declare that they have no competing interest.

Received for publication: 18 August 2020.

Accepted for publication: 23 December 2020.

oCopyright: the Author(s), 2021

Licensee PAGEPress, Italy

Journal of Public Health Research 2021;10:1904

doi:10.4081/jphr.2021.1904

This work is licensed under a Creative Commons Attribution NonCommercial 4.0 License (CC BY-NC 4.0).

\section{References}

1. Chen N, Zhou M, Dong X, et al. Epidemiological and clinical characteristics of 99 cases of 2019 novel coronavirus pneumonia in Wuhan, China: a descriptive study. Lancet
2020;395:507-13.

2. The Lancet. COVID-19: learning from experience. Lancet 2020;395:1011.

3. Young BE, Ong SWX, Kalimuddin S, et al. Epidemiologic features and clinical course of patients infected with SARS-CoV2 in Singapore. JAMA 2020;323):1488-94.

4. Patel J, Nielsen F, Badiani A, et al. Poverty, inequality and COVID-19: the forgotten vulnerable. Public Health 2020;183:110.

5. Kunst AE, Mackenbach JP. Measuring socio-economic inequalities in health. NIH Conference Measuring social inequalities in health, Annapolis, 1994.

6. Kim SJ, Bostwick W. Social vulnerability and racial inequality in COVID-19 deaths in Chicago. Health Educ Behav 2020;47:509-13.

7. Berkman LF, Kawachi I, Glymour MM. Social epidemiology. Oxford University Press: Oxford; 2014.

8. WHO. A conceptual framework for action on the social determinants of health. 2010. World Health Organization. Available from: https://apps.who.int/iris/handle/10665/44489

9. Alcendor DJ. Racial disparities-associated COVID-19 mortality among minority populations in the US. J Clin Med 2020;9:2442.

10. Jahromi AH, jahromi A. Why African Americans are a potential target for COVID-19 infection in the United States. J Med Internet Res 2020;22:e19934.

11. Phillips N, Park I-W, Robinson JR, Jones HP. The perfect storm: COVID-19 health disparities in US Blacks. J Racial Ethn Health Disparities 2020. doi: 10.1007/s40615-02000871-y

12. Shadmi E, Chen Y, Dourado I, Faran-Perach I, et al. Health equity and COVID-19: global perspectives. Int J Equity Health 2020;19:1-16.

13. SoleimanvandiAzar N, Kamal SHM, Sajjadi H, et al. Determinants of outpatient health service utilization according to Andersen's Behavioral Model: A systematic scoping review. Iran J Med Sci 2020;45:405.

14. Gentilini U, Almenfi M, Orton I, Dale P. Social protection and jobs responses to COVID-19: A real-time review of country measures. 2020. World Bank Group. Available from: https://socialprotection.org/discover/publications/social-protection-and-jobs-responses-covid-19-real-time-review-country

15. Gerard F, Imbert C, Orkin K. Social protection response to the COVID-19 crisis: options for developing countries. Oxford Rev Econ Policy 2020;36:S281-96.

16. Alizadeh M, Abbasi M, Bashirivand $N$, et al. Nongovernmental organizations and social aspects of COVID19 pandemic: A successful experience in health policy. Med J Islamic Republic Iran (MJIRI) 2020;34:1180-3. 